\begin{tabular}{|c|c|c|c|c|c|}
\hline \multirow{2}{*}{} & \multicolumn{3}{|c|}{ Week 12 } & \multicolumn{3}{c|}{ Week 28 } \\
\cline { 3 - 6 } & & \multicolumn{4}{|c|}{ Treatment group } \\
\cline { 2 - 6 } & $\mathrm{N}$ & PBO & DZP & PBO & DZP \\
\hline \multirow{4}{*}{ BICLA } & 7 & 11 & 6 & 10 \\
\cline { 2 - 6 } & Responders, $\mathrm{n}(\%)$ & $1(14.3)$ & $5(45.5)$ & $1(16.7)$ & $3(30.0)$ \\
\cline { 2 - 6 } & Non-responders, $\mathrm{n}(\%)$ & $6(85.7)$ & $6(54.5)$ & $5(83.3)$ & $7(70.0)$ \\
\hline \multirow{3}{*}{ SRI-4 } & N & 7 & 12 & 6 & 11 \\
\cline { 2 - 6 } & Responders, $\mathrm{n}(\%)$ & $1(14.3)$ & $5(41.7)$ & $1(16.7)$ & $4(36.4)$ \\
\cline { 2 - 6 } & Non-responders, $\mathrm{n}(\%)$ & $6(85.7)$ & $7(58.3)$ & $5(83.3)$ & $7(63.6)$ \\
\hline
\end{tabular}

BICLA, British Isles Lupus Assessment Group (BILAG)-based Composite Lupus Assessment; DZP, dapirolizumab pegol; PBO, placebo; SRI-4, Systemic Lupus Erythematosus Responder Index-4

systemic lupus erythematosus (SLE). We report data from a Phase I double-blind, multiple dose study (NCT01764594) of dapirolizumab pegol (DZP), a PEGylated anti-CD40L Fab' fragment, in SLE patients.

Methods Twenty-four SLE patients were randomised (2:1, stratified by the presence of anti-phospholipid antibodies) to receive DZP (loading dose $30 \mathrm{mg} / \mathrm{kg}$, then $15 \mathrm{mg} / \mathrm{kg}$ every 2 weeks for 10 weeks) or placebo. Patients were followed for 18 weeks. Objectives: safety and tolerability of DZP (primary); disease activity measures (BICLA and SRI-4; exploratory). Genes expressed by plasma cells, B cells, other immune cells and transcripts associated with SLE disease activity were analysed by qPCR.

Results No serious adverse events (AEs), thromboembolic events or deaths occurred. Most treatment-emergent AEs (TEAEs) were mild or moderate, transient, and resolved without intervention. Nasopharyngitis was the most common TEAE (6 patients in the DZP group; none with placebo). One patient withdrew due to upper respiratory tract infection (DZP group). Of DZP-treated patients evaluable for BICLA and SRI-4, 46\% and 42\% respectively, responded by Week 12 (vs 14\% placebo; Table 1). Rapid and maintained mechanismrelated gene expression changes were observed, particularly in plasma cell genes (IgA, IgG, IgJ) from the DZP group.

Conclusions DZP was well tolerated and demonstrated improvement in clinical measures of disease activity. A Phase II study is evaluating efficacy and safety of DZP in SLE patients (NCT02804763).

\section{POTENTIAL NOVEL NATURAL B CELL DEPLETING AND IMMUNOSUPPRESSION AGENT IN LUPUS TREAPMENT USING BRYOPHYLLUM PINNATUM.IN SILICO AND IN PRISTANE INDUCED LUPUS MICE}

\footnotetext{
${ }^{1} \mathrm{U}$ Kalsum*, ${ }^{1} \mathrm{~N}$ Nurdiana, ${ }^{2} \mathrm{MZ}$ Pratama, ${ }^{3} \mathrm{H}$ Kalim, ${ }^{1} \mathrm{~K}$ Handono. ${ }^{1}$ Medical Faculty Brawijaya University, Clinical Pharmacology, Malang, Indonesia; ${ }^{2}$ Medical Faculty Brawijaya University, Internal Medicine, Malang, Indonesia; ${ }^{3}$ Medical Faculty Brawijaya University, Rheumato-Immunology, Malang, Indonesia
}

Background and aims The purpose of this study is to use in silico molecular docking and in vivo study to identify the potential of Bryophyllum pinnatum as B cell depleting and immune suppression agent in SLE.

Methods In silico was done by docking 32 phytochemical compounds well known immunosuppresive herbs into three B cell activating receptors: B cell activating factor receptors (BAFF-R), trans- membrane activator and calcium modulator and cyclophilin ligand interactor (TACI), and B-cell maturation antigen (BCMA). In vivo study was done in pristane induced mice model treated with different doses of Bryophyllum pinnatum extract (B1 :10.5 mg/kgBW/day, B2 :21 mg/kgBW/day, and $\mathrm{B} 3: 42 \mathrm{mg} / \mathrm{kgBW} /$ day). Extracts were given everyday per orally from 3rd to 4th months after pristane injection. spleen mature B cell $\left(\mathrm{CD} 19^{+} \mathrm{CD} 22^{+}\right)$, Th1,Th2 and Th17 percentages were assessed using flow cytometry assay and serum anti-dsDNA level using ELISA.

Results It was revealed that one compound from Bryophyllum pinnatum had the strongest binding affinity to BAFF-R $(-6.3 \mathrm{kcal} / \mathrm{mol}$ ), to TACI (four compounds, $-6.4 \mathrm{kcal} / \mathrm{mol}$ ) and to BCMA $(-7 \mathrm{kcal} / \mathrm{mol})$. In vivo study revealed that Bryophyllum pinnatum treatment significantly lower the percentages of $\mathrm{CD} 19^{+} \mathrm{CD} 22^{+}$cell and anti-dsDNA levels in dose dependent manner which significantly lower compared to control $(\mathrm{p}=0.002$ and $\mathrm{p}=0.036$ respectively). Bryophyllum pinnatum treatment lowered also Th1, Th2, and Th17 percentages dose dependently compared to control.

Conclusions Bryophyllum pinnatum is a potential natural product which may be used for B cell depleting agent in SLE treatment by suppressing Th1, Th2 and Th17 percentages.

\section{EFFECT OF CURCUMIN AND VITAMIN D ON DISEASE ACTIVITY, FATIGUE, AND CYTOKINE PROFILE IN SYSTEMIC LUPUS ERYTHEMATOSUS PATIENTS WITH DEFICIENCY VITAMIN D}

CS Wahono*, H Kalim, I Saveria, CD Setyorini, Z Wahyuni, RA Dimpudus, H Kusworini. Medical Faculty Brawijaya University, Rheumato-Immunology, Malang, Indonesia 
Background and aims SLE patient who had deficiency of vitamin D, had worsen clinical manifestation. Vitamin D and Curcumin ; a novel Vitamin D Receptor (VDR) ligand, are immunomodulator. The purpose of this study, to compare efficacy whether curcumin supplementation in vitamin D treatment will give improvement of disease activity, fatigue and proteinuria in SLE patient with vitamin D deficiency.

Methods This study was a double blind RCT included 40 active SLE patient more than 18 yo with level 25(OH)D3 $\leq 30 \mathrm{ng} / \mathrm{ml}$ were enrolled for this study. There were divided into 2 group, control group who received cholecalciferol $3 \times$ 400 IU plus placebo and trial group who received cholecalciferol $3 \times 400 \mathrm{IU}$ and curcumin $3 \times 20 \mathrm{mg}$ for 6 months. Demorgrafic data, family history, medications, laboratory test, SLEDAI and FSS were taken before and after treatment. Serum cytokines were measure uisng ELISA. The results between 2 groups were evaluated with independent t-test and spearman/pearson correlation test using SPSS software.

Results Age of participant are 28.1 \pm 8.1 , disease duration 3.1 \pm 2.3 year. The addition of curcumin in the suplemtation treatment with vitamin D increase the benefit of vitamin D. Combination of curcumin and vitamin $\mathrm{D}$ result in better disease activity suppression, less fatigue and less proteinuria compare with vitamin D supplementation alone. The clinical improvement were related to decrease in proinflammatory cytokines ( IFNg, TNFa and IL-17 ). There were no major adverse events in both groups.

Conclusions The addition of curcumin to the vitamin D supplementation therapy result in better efficacy.

\section{IMMUNE MODULATION EFFECTS OF CURCUMIN IN PRISTANE INDUCED LUPUS MICE}

${ }^{1} \mathrm{H}$ Susiianti*, ${ }^{2} \mathrm{CS}$ Wahono, ${ }^{3} \mathrm{M}$ Zaka Pratama, ${ }^{1} \mathrm{U}$ Kalsum, ${ }^{1} \mathrm{~N}$ Nurdiana, ${ }^{2} \mathrm{H}$ Kalim. ${ }^{1}$ Brawijaya University, Clinical Pathology, Malang, Indonesia; ${ }^{2}$ Brawijaya University, Rheumato-Immunology, Malang, Indonesia; ${ }^{3}$ Brawijaya University, Internal Medicine, Malang, Indonesia

\subsection{6/lupus-2017-000215.93}

Background and aims The aim of this study is to assess the effect of curcumin treatment on the clinical manifestations, Th-cells subsets/Treg percentages, pro-inflammatory cytokines and autoantibody production of pristane induced lupus mice.

Methods Forty female Balb/c mice ( 6-8 weeks of age with body weight 30-50 gram ) were single injected with pristane intraperitoneally for lupus induction. The mice were assigned to 3 groups treated with 3 different doses of curcumin given $12.5 \mathrm{mg} /, 50 \mathrm{mg} /$, and $200 \mathrm{mg} / \mathrm{kgBW} /$ day. One group of mice as control was not tretaed with curcumin. The mice were monitored for clinical manifestations ( arthritis score, proteinuria, and body weight). After 32 weeks post injection, the spleens were taken and assayed for Th1, Th2, Th17, and Treg percentages using flow cytometry. Serum was collected for ANA, IL- 6 , and IFN- $\alpha$ measurement by ELISA.

Results Arthritis score was lower in all groups treated with curcumin $(p=0.000)$. However, proteinuria and body weights were not statistically different between all groups of mice.
ANA levels decreased significantly after treatment with $200 \mathrm{mg} / \mathrm{kgBW} /$ day of curcumin $(\mathrm{p}=0.024)$. The decreased of Th1, Th2, and Th17 percentages were also seen after treatment of $200 \mathrm{mg} / \mathrm{kgBW} /$ day of curcumin $(\mathrm{p}=0.043, \mathrm{p}=0.026$, and $\mathrm{p}=0.009$ ); however, only slight increase of Treg percentages was seen. Treatment with $200 \mathrm{mg} / \mathrm{kgBW} /$ day of curcumin decreased serum IL-6 and IFN- $\alpha$ levels $(p=0.012$ and $\mathrm{p}=0.003)$.

Conclusions Curcumin protects manifestation of arthritis in pristane induced lupus mice and ANA production, modulating Th-cell subsets, and inhibiting production of proinflammatory cytokines

\section{DEVELOPMENT OF THERAPY USING BRYOPHYLLUM PINNATUM TO DECREASE MATURATION AND INCREASE APOPTOTIC B CELLS FROM BALB/C LUPUS MICE: IN SILICO AND IN VITRO STUDY APPROACH}

${ }^{1} \mathrm{~K}$ Handono*, ${ }^{2}$ TWI Dantara, ${ }^{3}$ E.S. Dewi, ${ }^{4} \mathrm{MZ}$ Pratama, ${ }^{5} \mathrm{~N}$ Nurdiana. ${ }^{1}$ Faculty of Medicine Brawijaya University, Clinical Pathology, Malang, Indonesia; ${ }^{2}$ Faculty of Medicine Brawijaya University, Biomedical Science, Malang, Indonesia; ${ }^{3}$ Faculty of Medicine Brawijaya University, Medical Surgeon Nursing, Malang, Indonesia; ${ }^{4}$ Faculty of Medicine Brawijaya University, Internal Medicine, Malang, Indonesia; ${ }^{5}$ Faculty of Medicine Brawijaya University, Clinical Pharmacology, Malang, Indonesia

\subsection{6/lupus-2017-000215.94}

Background and aims To investigate the effect of Bryophyllum pinnatum extract to $\mathrm{B}$ cells by supressing maturation and increasing apoptosis of B cells.

Methods In silico study was done to understand affinity of Bryophillin A, Bryophillin B, Bryotoxin A, Bryotoxin B, Kaempferol, p-coumaric acid aiffinity in Bryophyllum pinnatum against $\mathrm{B}$ cell activating factor (BAFF) and its receptors: $\mathrm{B}$ cell activating factor receptors (BAFF-R), transmembrane activator and calcium modulator and cyclophilin ligand interactor (TACI), and B-cell maturation antigen (BCMA). In vitro study was done by culturing $\mathrm{B}$ cells from pristane induced lupus BALB/c mice's spleen. B cells were cultured into four groups, one as a control and the other groups given Bryophyllum pinnatum extract $(0.02,0.1$, and $0.5 \mathrm{ug} / \mathrm{L})$. Precentage of maturation $\left(\mathrm{CD} 19^{+} / \mathrm{CD} 38^{+}\right)$and apoptosis (Annexin $\mathrm{V}^{+} / \mathrm{PI}^{+}$) of $\mathrm{B}$ cells determined using flow cytometry. Immunocytochemistry assay was performed to determine the expression of transcription factor NF-kB p65.

Results Molecular docking results show that all of Bryophyllum pinnatum compounds studied have affinities for BAFF-R, TACI, BCMA and BAFF. Flow cytometry assay showed significantly decrease in percentages of maturation of $\mathrm{B}$ cells in all doses $(p<0.05)$, significantly increase in percentages of apoptotic B cells in dose $0.5 \mathrm{ug} / \mathrm{L}(\mathrm{p}<0.05)$. The results of immunocytochemistry showed decreased expression of NF-kB p65 were significant at all doses $(\mathrm{p}<0.05)$.

Conclusions In silico and in vitro study revealed that Bryophyllum pinnatum is potential natural product which may be used for B cell depleting agent in development of biosimilar therapy in systemic lupus erythematosus. 